\title{
AMENDED DESCRIPTION OF THE SUMATRAN ENDEMIC DENDROBIUM BANDII (ORCHIDACEAE) WITH NOTES ON ITS CONSERVATION STATUS AND ECOLOGY
}

\author{
Mark Arcebal K. Naive ${ }^{1,2,6}$, Yuda Rehata Yudistira ${ }^{3}$, Malcolm Victoriano ${ }^{4}$ \\ \& PAUL ORMEROD 5
}

${ }^{1}$ Center for Integrative Conservation, Xishuangbanna Tropical Botanical Garden, Chinese Academy of Sciences, Mengla, Yunnan 666303, China.

${ }^{2}$ University of Chinese Academy of Sciences, Beijing 100049, China.

${ }^{3}$ Menteng Square A20-12, J1. Matraman No. 30E, Senen, Jakarta Pusat, 10430, Indonesia.

${ }^{4}$ Indonesian Carnivorous Plant Society. Jl. Manggis 52, Jakasetia, Bekasi City, 17147, Indonesia.

${ }^{5}$ P.O. Box 8210, Cairns, Qld., 4870, Australia.

${ }^{6}$ Author for correspondence: arciinaive19@gmail.com

\begin{abstract}
Dendrobium bandii is a poorly known species endemic to the island of Sumatra, Indonesia. We studied living specimens and we provide here an amended description of the species, colour photographs, as well as information on distribution, ecology, and its provisional conservation status.
\end{abstract}

Key words: Dendrobieae, Epidendroideae, Malesian Flora, plant taxonomy, Sumatran biodiversity

Introduction. Dendrobium Sw., belonging to the tribe Malaxideae, subtribe Dendrobiinae, is the third largest orchid genus encompassing about 1600-1800 species distributed from Sri Lanka throughout tropical Asia and the Pacific region, north to Japan, east to Tahiti and south to New Zealand (Schuiteman \& Adams 2014, Chase et al. 2015, Ormerod 2017). At present, the number of Dendrobium species in Indonesia is around 680 species (Ormerod unpubl. data). In Sumatra, the genus is represented by approximately 140 species and future fieldwork would probably result in the discovery of more species either endemic or as new records from neighbouring countries and islands (Juswara et al. 2018).

In the recent floristic survey conducted in the westernmost province of Indonesia by the second and third authors, an unknown Dendrobium species was collected in the province of Aceh, Sumatra. Upon detailed morphological examination and comparison to the relevant literature and digitized type specimens of Dendrobium from Indonesia and neighbouring countries, the species matches with $D$. bandii Cavestro, a poorly known species recently described.

A careful analysis of our recently collected specimen revealed that the description and line drawing provided by Cavestro (2020) are not entirely accurate: the diagnosis and some morphological characters recorded by the author (e.g. acute to obtuse leaf apex, oblong-triangular lateral sepals, broadly ovate midlobe of the labellum, column length, among others) are probably more variable than the protologue suggests, and some morphometric features were omitted in the original description (e.g. column foot measurement, claw measurement, stelidia shape and measurement and many more). Thus, to further clarify the identity of this taxon, we present here an amended description of $D$. bandii, a colour photograph to aid accurate identification, ecological notes and its provisional conservation status.

Materials and methods. The measurements and descriptions were based on freshly collected material deposited at Herbarium Bogoriense (BO). The general plant descriptive terminology follows Beentje (2016). Informal conservation status category was assessed by range size (B criterion), following IUCN Standards and Petitions Subcommittee (2019) recommendations. The extent of occurrence (EOO) and area of occupancy (AOO) were estimated using GeoCAT (Bachman et al. 2011).

\section{TAXONOMIC TREATMENT}

Dendrobium bandii Cavestro, Orchidee (Hamburg) 6(120): 176, 2020. TYPE: INDONESIA. North Sumatra: District of Aceh, elev. ca. 1300-1600 m, 


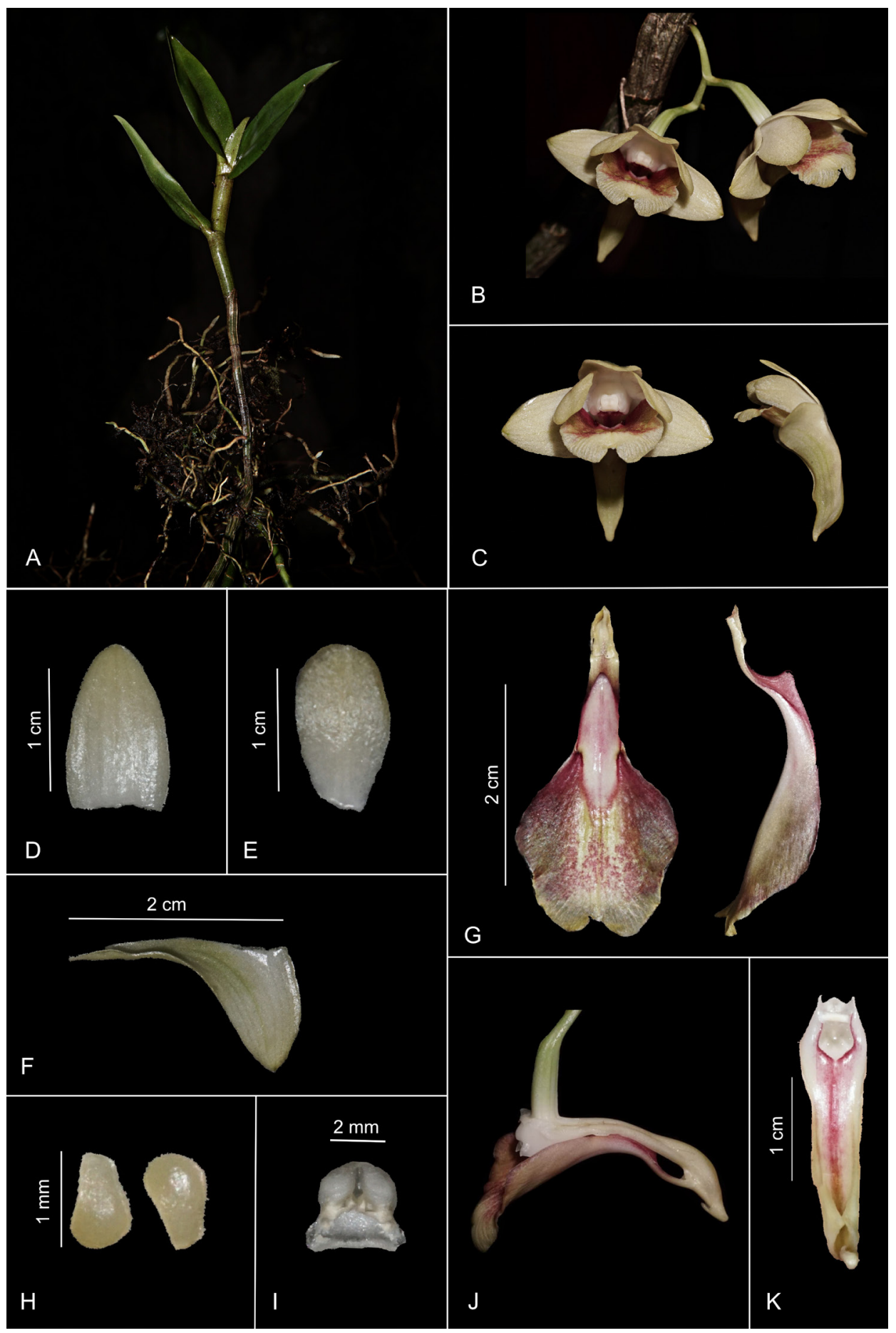

Figure 1. Dendrobium bandii Cavestro. A. Habit. B. Inflorescence. C. Flower (left, front view; right, profile view). D. Dorsal sepal. E. Petal. F. Lateral sepal. G. Labellum (left, top view; right, profile view). H. Pollinia. I. Anther cap. J. Pedicel with ovary, profile view of column, column foot and labellum. K. Ventral view of column and column foot. Photos by Y. R. Yudistira. 
18 February 2020, W. Cavestro and A. Marup s.n. (holotype, ANDA). Fig. 1.

Epiphytic, pendent, herb. Roots elongate, ca. 1.5 $\mathrm{mm}$ long, glabrous. Stem slightly flexuous, $15-40 \mathrm{~cm}$ long by $0.3-1.2 \mathrm{~cm}$ in diameter, terete at the base, slightly flattened in $2 / 3$ of the upper part, young stem rounded, green; internodes ca. 1.5-4 cm long. Leaves distichous, deciduous; sheaths tubular, clasping the entire internode, brown; leaf blades lanceolate-elliptic, $9.5 \mathrm{~cm}$ long by $3.0 \mathrm{~cm}$ wide, with 4 veins, chartaceous, green, glabrous, margin entire, apex subacuminate to acuminate. Inflorescence 2- or 3-flowered, arising from the older, leafless stems; peduncle 10-11 mm long, terete, glabrous. Flower $2.5 \mathrm{~cm}$ across, apricot or orange pink to yellow or greenish yellow with crimson spots on the labellum and the ventral side of the column foot. Pedicel and ovary $13 \mathrm{~mm}$ long, corrugated, glabrous, pale green, whitish near apex. Dorsal sepal 3-veined, incurved, nodding, ovate, $15 \mathrm{~mm}$ long by 8-9 mm wide, glabrous, covering the column, margin entire, apex obtuse. Lateral sepals 7-veined, spreading, broadly falcate, $15-16 \mathrm{~mm}$ long by $20-23 \mathrm{~mm}$ wide, glabrous, forming a mentum with the column foot 20-21 mm long, margin entire, apex acute, cucullate. Petals 1-veined, pointing forward, obovate, $15 \mathrm{~mm}$ long by $5-7 \mathrm{~mm}$ wide, glabrous, covering the column, margin entire, apex rounded. Lip $3.2 \mathrm{~cm}$ long by 1.8 $\mathrm{cm}$ wide; claw ligulate-oblong, subsigmoid in lateral view, basal $2-3 \mathrm{~mm}$ excavate and joined to column foot, free part ca. $7-8 \mathrm{~mm}$ long, in total ca. $10 \mathrm{~mm}$ long by $2-3 \mathrm{~mm}$ wide; blade weakly trilobed, broadly rhombic, $13-15 \mathrm{~mm}$ long by $12-14 \mathrm{~mm}$ wide, glabrous, margins slightly undulate to entire, fleshy, apex broadly, obtusely bilobed; callus oblong, shallowly canaliculate, base raised, obtuse, slightly retrorse, beginning midway on the claw and terminating on the basal quarter of the blade; mentum narrowly-conical, $2.0-2.1 \mathrm{~cm}$ long, curved, acute. Column stout, 3-4 mm long, with a crimson stripe on the underside; column foot 20-21 mm long; stelidia triangular, $1.0-1.5 \mathrm{~mm}$ long; pollinia 2 , each pair can be divided into two parts, $1 \mathrm{~mm}$ long by $1.3 \mathrm{~mm}$ across, yellowish; anther-cap cucullate, $3 \mathrm{~mm}$ across, subhyaline. Capsule not seen.

DistRIBUTION: Restricted to four localities, including its type locality and the highlands of Aceh Province at an elevation of 800-1600 m a.s.1., from Aceh Tengah to Bener Meriah and Nagan Raya.

HaBitat: Growing epiphytically on trees in primary forests and secondary forests, and also found thriving in coffee plantations.

Phenology: Flowering almost all year round.

Eponymy: The specific epithet was derived after the discoverer of the species, Subandi Bandi.

Provisional CONSERVATION Status: There are four localities known for this species, including the type locality. Each locality has a few populations in a limited area, giving an approximate Area of Occupancy (AOO) of $12 \mathrm{~km}^{2}$ when calculated in the GeoCAT system (Bachman et al. 2011). Following the Red List criteria of the IUCN Standards and Petitions Subcommittee (2019), the species would fall into the IUCN category of Endangered [EN B2ab(ii)].

SPecimen eXAmIned: INDONESIA. Sumatra: Aceh Province, Aceh Tengah Regency, Jagong Jeget, elev. 1500 m, 20 January 2020, Victori 004 (BO!, including spirit collection).

Dendrobium bandii was originally compared to another Sumatran species, D. transtilliferum J.J.Sm., but the latter taxon differs in having a broader, more open mentum, a cuneate (not clawed) labellum, and a flat, truncate suprabasal (vs. a raised rounded) callus. Dendrobium bandii is closer to D. sanguinoletum Lindl., sharing with it a similar mentum shape, and similar labellum shape with the callus placed in about the same area on the claw. However, D. bandii differs significantly in having forward-pointing, obovate petals ( $v s$. spreading, spatulate petals in D. sanguinolentum), a narrowly conical, subacute mentum ( $v s$. oblongoid, truncate mentum in $D$. sanguinolentum), and a labellum with an obtuse, slightly retrorse callus base (vs. acute, strongly retrorse, spinelike callus base in $D$. sanguinolentum). It also differs in having an apricot to yellow or greenish-yellow coloured flowers with crimson spots or colouration in the labellum, whereas $D$. sanguinolentum has a yellow ochre or buff flower colour with or without a variable amount of rosered colour on the tips of sepals, petals, and lip. 
Acknowledgements. We would like to thank Nur Rohman for accompanying the second author during fieldwork, Ba Vuong Truong for providing us some relevant literature used in this study, and Wewin Tjiasmanto of Tjiasmanto Conservation Fund for his unwavering support.

\section{LITERATURE CITED}

Bachman, S., Moat, J., Hill, A., de la Torre, J. \& Scott, B. (2011). Supporting Red List threat assessments with GeoCAT: Geospatial Conservation Assessment Tool. ZooKeys, 150, 117-126.

Beentje, H. (2016). The Kew plant glossary: an illustrated dictionary of plant terms. 2nd edition. Kew, Richmond: Kew Publishing, Royal Botanic Gardens. 184 pp.

Cavestro, W. (2020). Dendrobium bandii Cavestro - a new species from Aceh Province, North Sumatra, Indonesia. Die Orchidee, 6(20), 170-176.

Chase, M. W., Cameron, K. M., Freudenstein, J. V., Pridgeon, A. M., Salazar, G., van den Berg, C. \& Schuiteman, A. (2015). An updated classification of Orchidaceae. Botanical Journal of the Linnean Society, 177, 151-174.

IUCN (2019). Guidelines for Using the IUCN Red List Categories and Criteria. Version 14. Prepared by the Standards and Petitions Committee. Retrieved from http://www.iucnredlist.org/documents/RedListGuidelines.pdf [Accessed on 21 September 2020]

Juswara, L. S., Schuiteman, A., O’Byrne, P. \& Champion, J. (2018). Dendrobium fitrianum (section Pedilonum, Orchidaceae), a new species from Sumatra. OrchideenJournal, 6(1), 3-5.

Ormerod, P. (2017). Checklist of Papuasian Orchids. Australia: Nature \& Travel Books.

Schuiteman, A. \& Adams, P. B. (2014). Dendrobium. In: A. M. Pridgeon, P. J. Cribb, M. W. Chase F. N. Rasmussen (eds.), Genera Orchidacearum, vol. 6. Epidendroideae (Part three). Oxford: Oxford University Press. 